\title{
COVID-19 implications at the Clinical University Center in Kosovo - Department of Pediatrics
}

\author{
Lidvana Spahiu $^{1}$, Egzona Berisha ${ }^{1}$, Emir Behluli ${ }^{1}$, Rifat Hadziselimovic ${ }^{1,2}$, Hilada Nefic ${ }^{1,2}$, \\ Gazmend Temaj ${ }^{3}$
}

\begin{abstract}
${ }^{1}$ Department of Pediatric, University Clinical Center, Prishtina, Kosovo ${ }^{2}$ Faculty of Sciences, University of Sarajevo, Sarajevo, Bosnia and Herzegovina ${ }^{3}$ College UBT, Faculty of Pharmacy, Prishtina, Kosovo
\end{abstract}

Submitted: 19 February 2021

Accepted: 29 May 2021

Arch Med Sci Civil Dis 2021; 6: e61-e67

DOI: https://doi.org/10.5114/amscd.2021.107844

Copyright @ 2021 Termedia \& Banach

\begin{abstract}
Introduction: In late December 2019, the first pneumonia cases of unknown origin were identified in Wuhan, the capital city of Hubei province in central China. While the most data are available for adult patients with COVID-19, limited reports analyze pediatric patients infected with SARS-CoV-2. The aim of the study was to describe the epidemiological and clinical characteristics of coronavirus disease (COVID-19) in patients at the Pediatric Clinical Center of Kosovo.

Material and methods: This research is retrospective and includes data for the period from 8 July 2020 to 6 January 2021. In this study we obtained data from different documents and patients' records, providing information regarding gender, age, number of cases, most frequent diagnosis, critical patients, etc.

Results: Out of 69 pediatric patients hospitalized in the clinic during the seven months, 50 patients tested positive with COVID-19. The study sample represented an equal number of males and females (50/50), while the average age of the patients was 6 years. Based on the pediatric age groups, the study sample comprises 16 patients of the age groups of 1 month-2 years, 20 patients of the age group of 2-6 years; 4 patients of the age group of 6-12 years, and 10 patients of the age group of 12-18 years.

Conclusions: Data suggest that pediatric cases of COVID-19 in adolescents have more severe symptoms than in the other age groups; however, in general children tend to cope much more easily with the virus than adults.
\end{abstract}

Key words: COVID-19, multisystem inflammatory syndrome in children, pediatric patients.

\section{Introduction}

The first pneumonia cases of unknown origin were identified in Wuhan in December 2019, the capital city of Hubei province in central China [1]. The causative pathogen was identified as a novel enveloped RNA $\beta$-coronavirus. In December 2019 the SARS-CoV-2 infection emerged. Very soon, SARS-CoV-2 spread across the globe and caused a pandemic situation, and thus SARS CoV-2 has become a major health concern $[2,3]$. The WHO on June 1,2020 , reported a total of $17,057,853$ cases worldwide with 690,166 deaths due to COVID-19 [4]. It is known that coronaviruses belong to the family of the Coronaviridae, and consist of

\author{
Corresponding author: \\ Gazmend Temaj PhD \\ College UBT \\ Faculty of Pharmacy \\ Prishtina, Kosovo \\ E-mail: gazmend.temaj@ \\ ubt-uni.net
}


four genera, namely Alphacoronavirus, Betacoronavirus, Gammacoronavirus and Deltacoronavirus. SARS-CoV-2 is part of the Betacoronavirus genus [5]. Like all coronaviruses, SARS-CoV-2 appears to be a positive-strand, non-segmented RNA virus. The coronaviruses have the largest genome among all RNA viruses, 27-32 kDa [6]. Clinical features of SARS-CoV-2 infection are similar to SARS and MERS. The shape of SARS-CoV-2 is spherical and pleomorphic [7]. SARS-CoV-2 has a single-stranded, non-segmented, positive-sense RNA. Most of the genomic material constitutes gene replicase; the replicase codes 16 nonstructural proteins (nSPs) [3, 8]. Transmission [9] of SARS-CoV-2 (severe acute respiratory syndrome coronavirus 2) occurs via respiratory droplets from face-to-face contact, and to a lesser degree, via contaminated surfaces. It turned out that aerosol spread may occur, but the role of aerosol spread in humans remains unclear. It is known that $48 \%$ to $62 \%$ of transmission may occur via pre-symptomatic carriers.

The most common symptoms [10] in hospitalized patients include fever (70-90\%), dry cough (60-86\%), shortness of breath (53-80\%), fatigue (38\%), myalgias (15-44\%), nausea/vomiting or diarrhea (15-39\%), headaches, weakness (25\%), and rhinorrhea (7\%). Anosmia or ageusia may be the sole presenting symptom in approximately $3 \%$ of individuals with COVID-19. Common laboratory abnormalities [11] among hospitalized patients include lymphopenia (83\%), elevated inflammatory markers (e.g., erythrocyte sedimentation rate (ESR), C-reactive protein (CRP), ferritin, tumor necrosis factor- $\alpha$, IL-1, IL-6), and abnormal coagulation parameters (e.g., prolonged prothrombin time, thrombocytopenia, elevated D-dimer (46\% of patients), low fibrinogen).

The most common complications among hospitalized patients with COVID-19 include pneumonia (75\%); acute respiratory distress syndrome (15\%); acute liver injury, characterized by elevations in aspartate transaminase, alanine transaminase, and bilirubin (19\%); cardiac injury, including troponin elevation (7-17\%), acute heart failure, dysrhythmias, and myocarditis; prothrombotic coagulopathy resulting in venous and arterial thromboembolic events (10-25\%); acute kidney injury (9\%); neurologic manifestations, including impaired consciousness (8\%) and acute cerebrovascular disease (3\%), and shock (6\%) [10, 12-16].

\section{Children infected with COVID-19}

While data are available mostly for adult patients with COVID-19, limited reports analyze pediatric patients infected with SARS-CoV-2. In this context, we performed a systematic review, to our knowledge, of COVID-19 in children and ad- olescents to evaluate clinical features, diagnostic tests, current therapeutic management, and prognosis at our University Clinical Center of Kosovo, the Pediatric Department.

In April 2020, during the peak of the coronavirus (COVID-19) pandemic in Europe, a cluster of children with hyperinflammatory shock with features similar to Kawasaki disease and toxic shock syndrome was reported in England [17]. The patients' signs and symptoms temporally were associated with COVID-19 but presumed to have developed 2-4 weeks after acute infection with COVID-19; all children had been tested by the serologic method and the evidence of infection with SARS-CoV-2, the virus that causes COVID-19, had been established. The clinical signs (symptoms) which were present in the first cluster included fever, rash, conjunctivitis, peripheral edema, gastrointestinal symptoms, shock, and elevated markers of inflammation and cardiac damage. At the beginning of May 2020, Centers for Disease Control and Prevention (CDC) published an online Health Advisory that summarized the manifestations of the reported multisystem inflammatory syndrome in children (MIS-C), outlined a case definition, and asked clinicians to report suspected U.S. cases to local and state health departments [18].

Multisystem inflammatory syndrome in children (MIS-C) is a new phenomenon that is reported worldwide with a temporal association with COVID-19. Multisystem inflammatory syndrome in children (MIS-C) is a very rare but severe condition, which has been reported approximately 2-4 weeks after the onset of COVID-19 in children and adolescents [18]. Distinguishing MIS-C from other severe diseases such as infectious or inflammatory conditions poses a challenge to clinicians caring for children and adolescents. The COVID-19 pandemic continues to expand in many ways; health care provider awareness of MIS-C will facilitate early recognition of infection, diagnosis, and treatment. Generally, children are known to have low immunity, and some exhibit a long incubation period after SARS-CoV-2 infection. Therefore, children should try to avoid contact with complex populations to avoid being infected by potential spreaders. COVID-19 is an acute, self-limiting disease; the mortality rate is $2 \%$, and it has also been reported as critical for children [19]. This paper aims to describe the epidemiological and clinical characteristics of coronavirus disease (COVID-19) pediatric patients at the Pediatric Clinical Center of Kosovo.

\section{Material and methods}

This is a retrospective study and includes data for the period from 8 July 2020 to 6 January 2021.

In this study, we obtained data from different documents and patients' records, providing us 
with information regarding: gender, age, number of cases, most frequent diagnosis, critical patients, etc.

The data collected in this research were processed using the MS Excel program wherein different formulas such as arithmetic mean, minimum, maximum, histogram, circular diagram, distribution polygon, and other graphs are used to better summarize the results of the study.

\section{Results}

In this study, there were in total 69 patients hospitalized in the clinic during the 7-month period, of whom 50 patients have tested positive with COVID-19. For this study, only patients who had tested positive with COVID-19 were selected for further analysis. From the gender perspective, males and females were represented equally, $50 / 50$, in the sample and the average age of the patients was 6 years (Figure 1).

Based on the pediatric age groups the study sample is composed of 16 patients of the age group of 1 month to 2 years, 20 patients of the age group of 2-6 years, 4 patients of the age group of 6-12 years, and 10 patients of the age group of 12-18 years. The average age of the patients was 6 years (Figure 2 ).

From this, we can see that the age groups of 2-6 years and 1 month to 2 years were more affected. The graph above shows the fluctuation of COVID-19 cases during the period from July 8 when the unit for COVID patients was established at our clinic, until January 2021. The study shows that the highest numbers of COVID-19 cases were recorded during October and November (Figure 3).

According to the data the most common diagnosis among the patients was bilateral bronchopneumonia and incipient pneumonia (24 cases), followed by Status febrilis (7 cases) and acute gastroenteritis (5 cases) (Table I, Figure 4).

The clinical state was defined according to the following classification: mild - uncomplicated upper respiratory tract viral infection (e.g., fever, cough, sore throat, malaise, headaches,

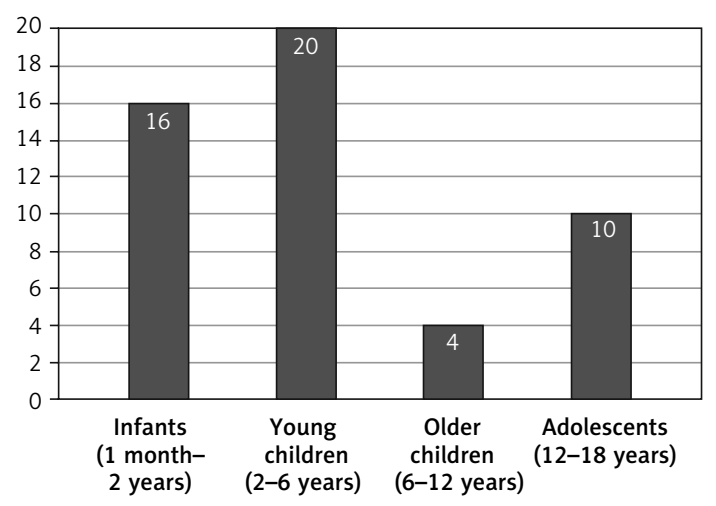

Figure 2. Pediatric group ages muscle pain); severe (e.g., pneumonia, hypoxia dyspnea, tachypnea requiring hospitalization), and multi-systemic inflammatory syndrome (e.g., severe pneumonia, acute respiratory distress syndrome, and/or multiple organ dysfunction requiring hospitalization in intensive care) (Figure 5).

Considering the clinical state in this study, we have focused on the sample of patients with critical conditions. Thus, four groups of patients will be described as follows.

The patients of the first group complained of having fever, cough, sore throat, and diarrhea. The laboratory examinations of this group were ESR $85 \mathrm{~mm} / \mathrm{h}$, leukocytes $8.3 \times 10^{-3} / \mathrm{mm}^{3}$, erythrocytes $4.40 \times 10^{-6} / \mathrm{mm}^{3}$, hemoglobin $12.4 \mathrm{~g} / \mathrm{dl}$, thrombocytes $388 \times 10^{-3} \mathrm{~mm}^{3}$, lymphocytes $27.2 \%$, monocytes 3.7 I and granulocytes $69.1 \%$. Level of urea $4.11 \mathrm{mmol} / \mathrm{L}$ (normal range: $1.70-8.30 \mathrm{mmol} / \mathrm{l}$ ), creatinine $89.9 \mathrm{mg} / \mathrm{dl}$ (normal range: $53-115 \mathrm{mg}$ / dl), aspartate transminase (AST) 59 IU/I (normal range: 2-37 IU/I), alanine transminase (ALT) 37.9 IU/I (normal levels: 3-4 IU/l), iron $33 \mu \mathrm{mol} / \mathrm{l}$ (normal range: 11.6-31.3 $\mu \mathrm{mol} / \mathrm{l})$, D-dimer $898 \mathrm{mg} / \mathrm{l}$ (normal range is till $255 \mathrm{ng} / \mathrm{ml}$ ), CRP $185 \mathrm{mg} / \mathrm{l}$ (normal range: 0-6 $\mathrm{mg} / \mathrm{l}$ ), estimated glomerular filtration rate (eGFR) $79.19 \mathrm{ml} / \mathrm{min} / 1.73 \mathrm{~m}^{2}$ (Table II). By further examination of the patients of this

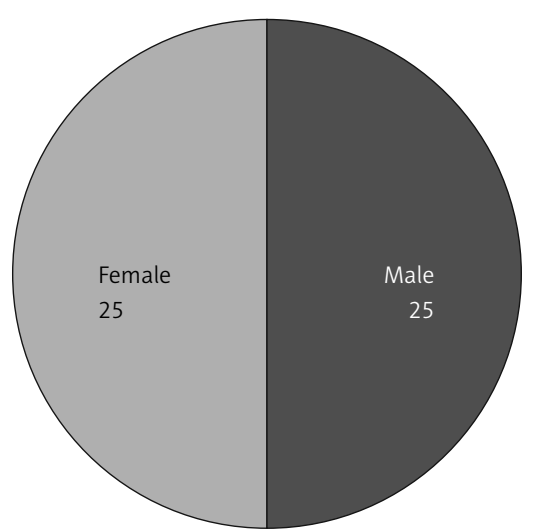

Figure 1 . The patient ratio by gender

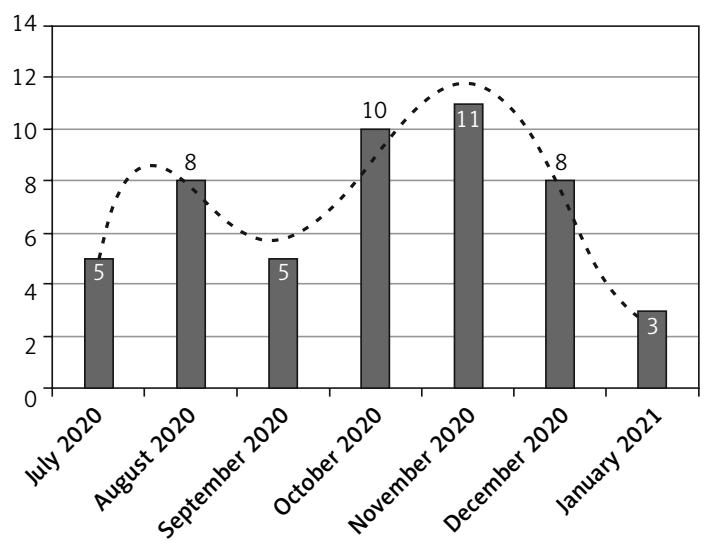

Figure 3. Number of cases from July 2020-January 2021 
Table I. Most frequent diagnoses among patients

\begin{tabular}{|lc|}
\hline Clinical cases & No. of cases \\
\hline $\begin{array}{l}\text { Bronchopneumonia billateralis } \\
\text { \& pneumonia incipiens }\end{array}$ & 24 \\
\hline Status febril & 7 \\
\hline Gastroenteritis acuta & 5 \\
\hline Other causes & 14 \\
\hline
\end{tabular}

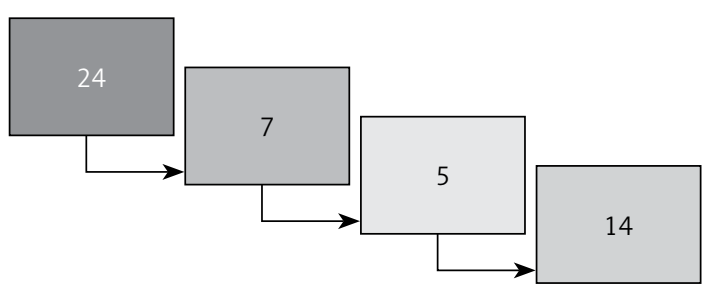

Figure 4. Most frequent diagnosis among patients

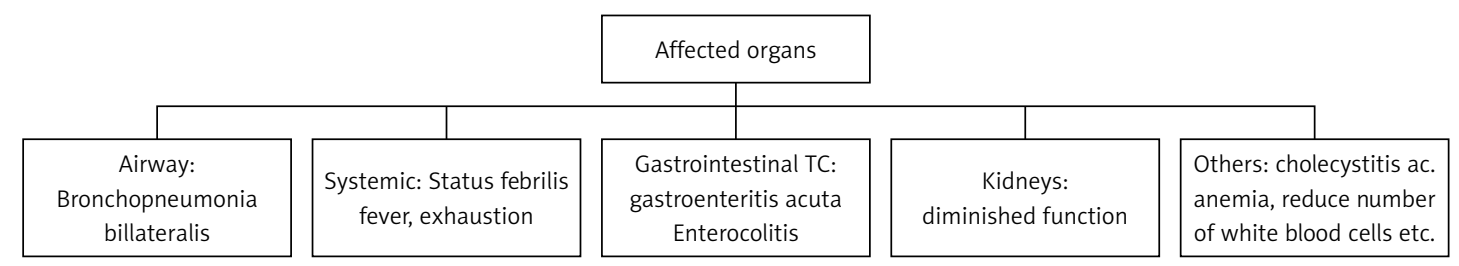

Figure 5. Cases with most the frequent symptoms

Table II. Average reported serum laboratory values for COVID-19 in four groups - Pediatric Clinical Center of Kosovo

\begin{tabular}{|c|c|c|c|c|c|}
\hline Parameter & Group 1 & Group 2 & Group 3 & Group 4 & $\begin{array}{c}\text { Normal value } \\
\text { of biochemical } \\
\text { and hematologi- } \\
\text { cal analysis }\end{array}$ \\
\hline ESR & $85 \mathrm{~mm} / \mathrm{h}$ & $90 \mathrm{~mm} / \mathrm{h}$ & $100 \mathrm{~mm} / \mathrm{h}$ & $50 \mathrm{~mm} / \mathrm{h}$ & $\begin{array}{l}M: 10 \mathrm{~mm} / \mathrm{h} \\
\mathrm{F}: 15 \mathrm{~mm} / \mathrm{h}\end{array}$ \\
\hline Leukocytes & $8.3 \times 10^{-3} / \mathrm{mm}^{3}$ & $10 \times 10^{-3} / \mathrm{mm}^{3}$ & $18.6 \times 10^{-3} / \mathrm{mm}^{3}$ & $\begin{array}{c}10.01 \times 10^{-3} / \\
\mathrm{mm}^{3}\end{array}$ & $4.0-8.0 \times 10^{9} / 1$ \\
\hline Erythrocytes & $4.40 \times 10^{-6} / \mathrm{mm}^{3}$ & $3.25 \times 10^{-6} / \mathrm{mm}^{3}$ & $4.32 \times 10^{-6} / \mathrm{mm}^{3}$ & $3.89 \times 10^{-6} / \mathrm{mm}^{3}$ & $\begin{array}{l}M: 4.5-5.8 \mathrm{~g} / \mathrm{l} \\
F: 3.8-4.9 \mathrm{~g} / \mathrm{l}\end{array}$ \\
\hline Hemoglobin & $12.4 \mathrm{~g} / \mathrm{dl}$ & $10.6 \mathrm{~g} / \mathrm{dl}$ & $10.9 \mathrm{~g} / \mathrm{dl}$ & $13.0 \mathrm{~g} / \mathrm{dl}$ & $\begin{array}{l}\text { M: } 140-180 \mathrm{~g} / \mathrm{l} \\
\mathrm{F}: 120-160 \mathrm{~g} / \mathrm{l}\end{array}$ \\
\hline Thrombocytes & $388 \times 10^{-3} \mathrm{~mm}^{3}$ & $108 \times 10^{-3} \mathrm{~mm}^{3}$ & $183 \times 10^{-3} \mathrm{~mm}^{3}$ & $288 \times 10^{-3} \mathrm{~mm}^{3}$ & $140-310 \times 10^{9} 1$ \\
\hline Lymphocytes & $27.2 \%$ & $10.0 \%$ & $9.1 \%$ & $12.7 \%$ & $25-33 \%$ \\
\hline Monocytes & 3.7 & 4.01 & 2.41 & 8.31 & $3-7 \%$ \\
\hline Granulocytes & $69.1 \%$ & $86.0 \%$ & $88.5 \%$ & $79 \%$ & $1.5-8.5 \times 10^{9} \mid$ \\
\hline Urea & 4.11 & 8.5 & 4.62 & 4.62 & $2.5-8.2 \mathrm{mmol} / \mathrm{l}$ \\
\hline Creatinine & $\begin{array}{l}89.9 \text { (normal } \\
\text { range: 53-115) }\end{array}$ & $\begin{array}{l}101 \text { (normal } \\
\text { range: 53-115) }\end{array}$ & $\begin{array}{l}113.9 \text { (normal } \\
\text { range: 53-115) }\end{array}$ & $\begin{array}{l}113.9 \text { (normal } \\
\text { range: } 53-115 \text { ) }\end{array}$ & $\begin{array}{c}\mathrm{M}: 70-108 \\
\mathrm{mmol} / \mathrm{l} \\
\mathrm{F}: 44-88 \mathrm{mmol} / \mathrm{l}\end{array}$ \\
\hline $\begin{array}{l}\text { AST (aspartate } \\
\text { transaminase) }\end{array}$ & 59 & 48 & 39 & 39 & $42 \mathrm{U} / \mathrm{l}$ \\
\hline $\begin{array}{l}\text { ALT (alanine ami- } \\
\text { notransferase) }\end{array}$ & 37.9 & 66 & 36 & 36 & $42 \mathrm{U} / \mathrm{l}$ \\
\hline Iron & $33 \mu \mathrm{mol} / \mathrm{l}$ & $36 \mu \mathrm{mol} / \mathrm{l}$ & $17 \mu \mathrm{mol} / \mathrm{l}$ & $17 \mu \mathrm{mol} / \mathrm{l}$ & $\begin{array}{c}\mathrm{M}: 10.667,79 \\
28.3 \mathrm{mmol} / \mathrm{l} \\
\mathrm{F}: 6.6-26.0 \\
\mathrm{mmol} / \mathrm{l}\end{array}$ \\
\hline D-dimer & 898 & 336 & 156.9 & 156.9 & $\begin{array}{c}\text { Normal range } \\
255\end{array}$ \\
\hline C-reactive protein & $\begin{array}{c}185 \mathrm{mg} / \mathrm{l} \\
\text { (normal range: } \\
0-6 \text { ) }\end{array}$ & $\begin{array}{c}156.8 \mathrm{mg} / \mathrm{l} \\
\text { (normal range: } \\
0-6 \text { ) }\end{array}$ & $\begin{array}{c}156.8 \mathrm{mg} / \mathrm{l} \\
\text { (normal range: } \\
0-6 \text { ) }\end{array}$ & $\begin{array}{c}113 \mathrm{mg} / \mathrm{l} \\
\text { (normal range: } \\
0-6 \text { ) }\end{array}$ & $0-6 \mathrm{mg} / \mathrm{l}$ \\
\hline $\begin{array}{l}\text { Estimated } \\
\text { glomerular } \\
\text { filtration rate }\end{array}$ & $\begin{array}{c}79.19 \mathrm{ml} / \mathrm{min} / \\
1.73 \mathrm{~m}^{2}\end{array}$ & $\begin{array}{c}65.92 \mathrm{ml} / \mathrm{min} / \\
1.73 \mathrm{~m}^{2}\end{array}$ & $\begin{array}{c}43.19 \mathrm{ml} / \mathrm{min} / \\
1.73 \mathrm{~m}^{2}\end{array}$ & $\begin{array}{c}67.79 \mathrm{ml} / \mathrm{min} / \\
1.73 \mathrm{~m}^{2}\end{array}$ & $\begin{array}{c}100 \mathrm{ml} / \mathrm{min} / \\
1.73 \mathrm{~m}^{2}\end{array}$ \\
\hline
\end{tabular}


group during hospitalization by chest radiography, we diagnosed incipient bronchopneumonia; by abdominal ultrasound: acute cholecystitis, in the meantime and also facial nerve paralysis and diminished renal function (Figure 6). The patient was treated with antibiotics (ceftriaxone $100 \mathrm{mg}$ / kg mt for $24 \mathrm{~h}$; amp. amikacin $15 \mathrm{mg} / \mathrm{kg} \mathrm{mt}$ for 24 h; amp. dexamethasone), imipenem (imipenem $50 \mathrm{mg} / \mathrm{kg}$ me for $24 \mathrm{~h}$ for 10 days), corticosteroids (methylprednisolone for $2 \mathrm{mg} / \mathrm{kg} \mathrm{mt}$ first day-day 10 16.4) and Fraxiparin, but when the general conditions deteriorated, a palliative care protocol was started (Table III).

The patients of the second group were children admitted for fever, blood in urine, dermatitis, and weakness. The laboratory examination findings of patients of this group were ESR $90 \mathrm{~mm} / \mathrm{h}$, leukocytes $10 \times 10^{-3} / \mathrm{mm}^{3}$, erythrocytes $3.25 \times 10^{-6} /$ $\mathrm{mm}^{3}$, hemoglobin $10.6 \mathrm{~g} / \mathrm{dl}$, thrombocytes $108 \times$ $10^{-3} \mathrm{~mm}^{3}$, lymphocytes $10.0 \%$, monocytes 4.0 । and granulocytes $86.0 \%$. Level of urea 8.5 (normal range: 1.70-8.30), creatinine 101 (normal range: 53-115), AST 48 (normal range: $2-37$ ), ALT 66 (normal levels: 3-41), iron $36 \mu \mathrm{mol} / \mathrm{l}$ (normal range: 11.6-31.3), D-dimer 336 (normal range:

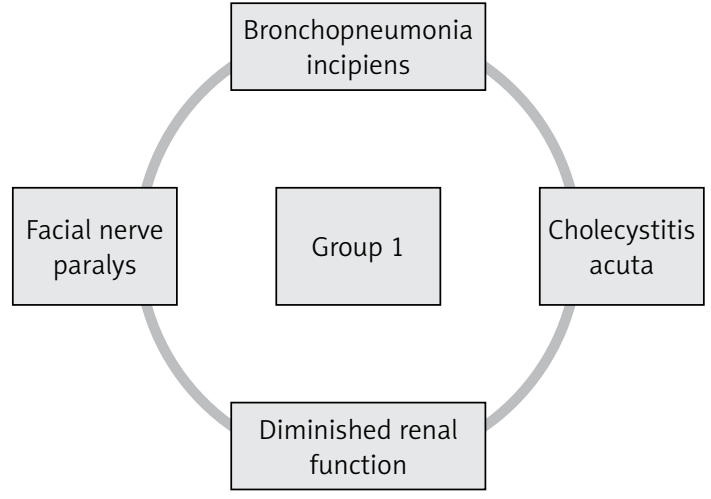

Figure 6. Patients of group one infected with virus SARS COVID-19 who have suffered from other diseases

255), CRP $156.8 \mathrm{mg} / \mathrm{l}$ (normal range: 0-6), eGFR $65.92 \mathrm{ml} / \mathrm{min} / 1.73 \mathrm{~m}^{2}$ (Table II). By further examination of the patients of this group during hospitalization by chest radiography, we diagnosed incipient bronchopneumonia; by abdominal ultrasound: splenomegaly, mesenteric lymphadenitis, according to blood analysis he had diminished renal function (Figure 7). The patient was treated with antibiotics (ceftriaxone vancomycin, dexa-

Table III. Treatment of patients with COVID-19 in pediatric clinical center of Kosovo

\begin{tabular}{|c|c|c|c|c|}
\hline & Group 1 & Group 2 & Group 3 & Group 4 \\
\hline $\begin{array}{l}\text { Drugs used } \\
\text { for patient } \\
\text { treatment }\end{array}$ & $\begin{array}{l}\text { Antibiotics (ceftriaxone } \\
100 \mathrm{mg} / \mathrm{kg} \text { mt for } \\
24 \mathrm{~h} \text {; amp. amikacin } \\
15 \mathrm{mg} / \mathrm{kg} \text { mt for } 24 \mathrm{~h} \text {; } \\
\text { amp. dexamethasone), } \\
\text { imipenem (imipenem } \\
50 \mathrm{mg} / \mathrm{kg} \text { me for } \\
24 \mathrm{~h} \text { for } 10 \text { days), } \\
\text { corticosteroids } \\
\text { (methylprednisolone } \\
\text { for } 2 \mathrm{mg} / \mathrm{kg} \text { mt first } \\
\text { day-day } 10 \text { 16.4) } \\
\text { Fraxiparin }\end{array}$ & $\begin{array}{l}\text { Antibiotics (ceftriaxone } \\
\text { vancomycin, } \\
\text { dexamethasone - for } \\
5 \text { days) corticosteroids } \\
\text { (methylprednisolone- } \\
\text { for } 5 \text { other days), } \\
\text { imipenem, } \\
\text { Fraxiparin }\end{array}$ & $\begin{array}{c}\text { Antibiotics } \\
\text { (vancomycin, } \\
\text { dexamethasone - for } \\
3 \text { days), corticosteroids } \\
\text { (methylprednisolone), } \\
\text { imipenem, } \\
\text { Fraxiparin }\end{array}$ & $\begin{array}{l}\text { Antibiotics (ceftriaxone } \\
\text { from the first day), } \\
\text { corticosteroids } \\
\text { (methylprednisolone- } \\
\text { from second day), } \\
\text { imipenem, } \\
\text { Fraxiparin }\end{array}$ \\
\hline
\end{tabular}

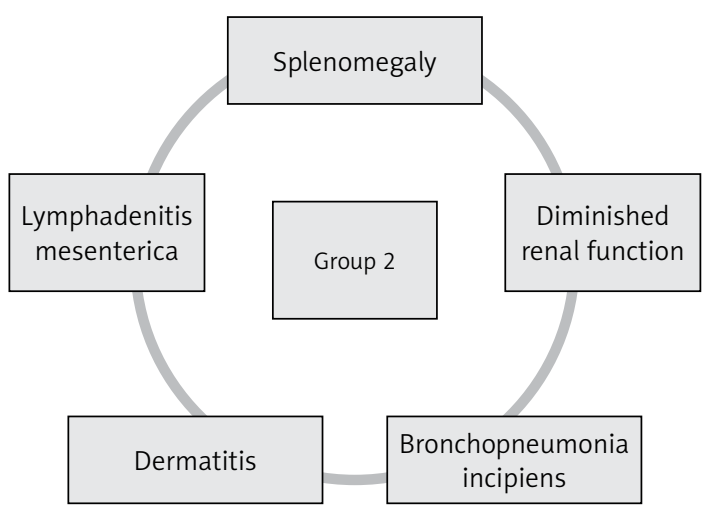

Figure 7. Patients of group two infected with the virus SARS COVID-19 who have also suffered from other diseases

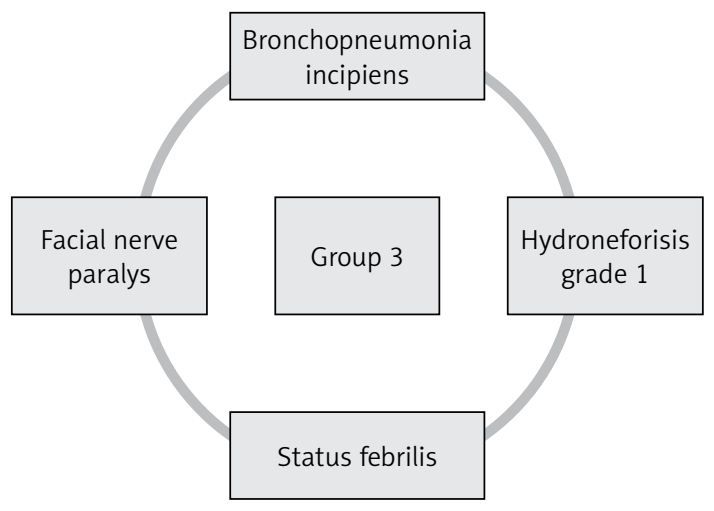

Figure 8. Patients of group three infected with the virus SARS COVID-19 who have also suffered from other diseases. The patients of the third group were children complaining of headaches, vomiting and temperature 


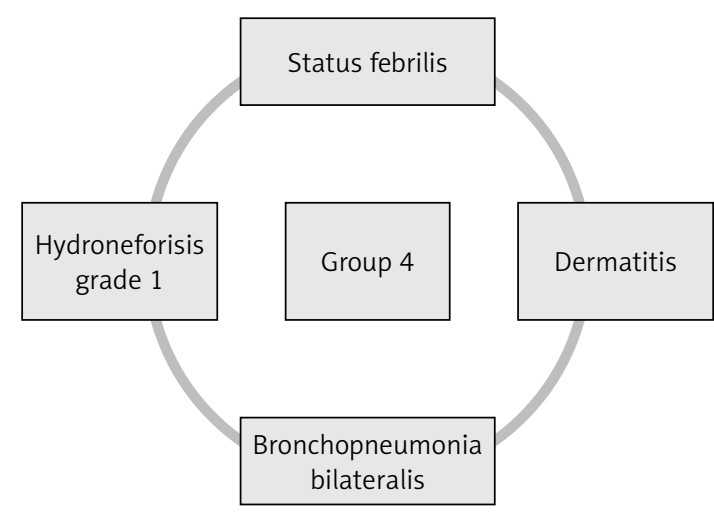

Figure 9. Patients of group four infected with the virus SARS COVID-19 who have also suffered from other diseases

methasone - for 5 days), corticosteroids (methylprednisolone - for 5 other days), imipenem, and Fraxiparin but when the general conditions deteriorated, a palliative care protocol was started (Table III).

The laboratory examination findings of patients from group three were ESR $100 \mathrm{~mm} / \mathrm{h}$, leukocytes $18.6 \times 10^{-3} / \mathrm{mm}^{3}$, erythrocytes $4.32 \times 10^{-6} /$ $\mathrm{mm}^{3}$, hemoglobin $10.9 \mathrm{~g} / \mathrm{dl}$, thrombocytes 183 $\times 10^{-3} \mathrm{~mm}^{3}$, lymphocytes $9.1 \%$, monocytes $2.4 \mathrm{l}$, and granulocytes $88.5 \%$. Level of urea 4.62 (normal range: 1.70-8.30), creatinine 113.9 (normal range: 53-115), AST 39 (normal range: $2-37$ ), ALT 36 (normal levels: 3-41), iron $17 \mu \mathrm{mol} / \mathrm{l}$ (normal range: 11.6-31.3), D-dimer 156.9 (normal range: 255), CRP $156.8 \mathrm{mg} / \mathrm{l}$ (normal range: 0-6), eGFR $43.19 \mathrm{ml} / \mathrm{min} / 1.73 \mathrm{~m}^{2}$ (Table II).

By further examination of the patients of group three during hospitalization by chest radiography we diagnosed bilateral bronchopneumonia; by abdominal ultrasound: hydronephrosis grade 1 , they also had facial nerve paralysis and diminished renal function (Figure 8). The patient was treated with antibiotics (vancomycin, dexamethasone for 3 days), corticosteroids (methylprednisolone), imipenem, and Fraxiparin but after the general conditions deteriorated, a palliative care protocol was started (Table III).

The last (fourth) group comprised children who suffered from dermatitis, temperature, and vomiting. The laboratory examination findings of patients of this group were ESR $50 \mathrm{~mm} / \mathrm{h}$, leukocytes $10.01 \times 10^{-3} / \mathrm{mm}^{3}$, erythrocytes $3.89 \times 10^{-6} /$ $\mathrm{mm}^{3}$, hemoglobin $13.0 \mathrm{~g} / \mathrm{dl}$, thrombocytes $288 \times$ $10^{-3} \mathrm{~mm}^{3}$, lymphocytes $12.7 \%$, monocytes 8.3 l, and granulocytes $79 \%$. Level of urea 4.62 (normal range: $1.70-8.30$ ), creatinine 113.9 (normal range: 53-115), AST 39 (normal range: 2-37), ALT 36 (normal levels: 3-41), iron $17 \mu \mathrm{mol} / \mathrm{l}$ (normal range: 11.6-31.3), D-dimer 156.9 (normal range: 255), CRP 113 mg/l (normal range: 0-6), eGFR 67.79 $\mathrm{ml} / \mathrm{min} / 1.73 \mathrm{~m}^{2}$ (Table II). By further examination of the patients of this group during hospitalization by chest radiography, we diagnosed bilateral bronchopneumonia; by abdominal ultrasound: hydronephrosis grade 1 (Figure 9). The patient was treated with antibiotics (ceftriaxone from the first day), corticosteroids (methylprednisolone from the second day), imipenem, and Fraxiparin but when the general conditions deteriorated, a palliative care protocol was started (Table III).

\section{Discussion}

Until April 2020, infection with SARS COVID-19 in children was asymptomatic or with mild symptoms. Herein we have reported about four groups of patients who were treated in our clinic. These patients had symptoms suggestive of a multi-system, hyper-inflammatory syndrome that are similar to some symptoms in inflammatory processes seen in children. The new symptoms have been called the multisystem inflammation syndrome in children related to COVID-19. The COVID-19 pandemic situation is continuing and the number of cases is the same or some days higher; healthcare providers should continue to monitor the ill children and to identify children with COVID-19 symptoms, such as lung hyper-inflammation, shock, and cardiac problems [4, 10, 12-16]. All our patients from four groups were tested for SARSCOVID-19 and all were positive.

The sample represented males and females equally, 50/50, and the average age of the patients was 6 years. If we consider such results, there is no specific impact on a specific gender.

Patients of the first group ( 1 month to 2 years old) and the second group (2-6 years old) were most affected because they tend to be less aware of the virus; this is because their immature immune systems and smaller airways make them more likely to develop breathing issues with respiratory virus infections, even though their symptoms were less severe than those observed in other group ages.

As of January 2021, 69 patients were hospitalized in our clinic, whereas the highest numbers of cases were recorded during October and November. Such findings support the fact that during those months the schools were open and certain measures were lifted by the government of our country. According to the study the most common diagnoses among all age groups are bronchopneumonia, Status febrilis (7 cases), and acute gastroenteritis, so this shows that there is no significant presence in a specific age group.

Finally, based on the medical records of 4 patients who had multisystemic inflammatory syndrome, 3 adolescents and 1 child had bronchopneumonia, systemic problems with Status febrilis fever, exhaustion and kidney function insufficien- 
cy, high levels of D-dimer, and other diagnoses. They were treated with antibiotics, imipenem, corticosteroids, and Fraxiparin. The patients had no record of any past diseases and after finishing the treatment for COVID-19 they were released home in a stable condition.

\section{Conflict of interest}

The authors declare no conflict of interest.

\section{References}

1. Guan WJ, Ni ZY, Hu Y, et al. Clinical characteristics of coronavirus disease 2019 in China. N Engl J Med 2020; 382: 1708-20.

2. Lai CC, Shih TP, Ko WC, Tang HJ, Hsueh PR. Severe acute respiratory syndrome coronavirus 2 (SARS-CoV-2) and coronavirus disease-2019 (COVID-19): the epidemic and the challenges. Int J Antimicrob Agents 2020; 55: 105924.

3. Guo YR, Cao QD, Hong ZS, et al. The origin, transmission and clinical therapies on coronavirus disease 2019 (COVID-19) outbreak - an update on the status. Mil Med Res 2020; 7: 11

4. World Health Organization. Coronavirus disease (COVID-19) Pandemic (2020). www.who.int/emergencies/diseases/novel-coronavirus-2019.

5. Bung N, Krishnan SR, Bulusu G, Roy A. De novo design of new chemical entities (NCEs) for SARS-CoV-2 using artificial intelligence. ChemRxiv 2020; 10.26434/chemrxiv.11998347.

6. Li F. Structure, function, and evolution of coronavirus spike proteins. Annu Rev Virol 2016; 3: 237-61.

7. Cascella M, Rajnik M, Cuomo A, Dulebohn SC, Di Napoli R. Features, evaluation and treatment coronavirus (COVID-19). FL, USA, StatPearls. StatPearls Publishing 2020.

8. Fehr AR, Perlman S. Coronaviruses: an overview of their replication and pathogenesis. In: Coronaviruses: Methods and Protocols. Maier H, Bickerton E, Britton P (eds). Humana Press 2015; 1-282.

9. Ganyani T, Kremer C, Chen D, et al. Estimating the generation interval for coronavirus disease (COVID-19) based on symptom onset data, March 2020. Euro Surveill 2020; 25: 2000257.

10. Mao R, Qiu Y, He JS, et al. Manifestations and prognosis of gastrointestinal and liver involvement in patients with COVID-19: a systematic review and meta-analysis. Lancet Gastroenterol Hepatol 2020; 5: 667-78.

11. Levi M, Thachil J, Iba T, Levy JH. Coagulation abnormalities and thrombosis in patients with COVID-19. Lancet Haematol 2020; 7: 438-40.

12. Long B, Brady WJ, Koyfman A, Gottlieb M. Cardiovascular complications in COVID-19. Am J Emerg Med 2020; 38: 1504-7.

13. Mao L, Jin $H$, Wang $M$, et al. Neurologic manifestations of hospitalized patients with coronavirus disease 2019 inWuhan, China. JAMA Neurol 2020; 77: 683-90.

14. Middeldorp S, Coppens M, van Haaps TF, et al. Incidence of venous thromboembolism in hospitalized patients with COVID-19. J Thromb Haemost 2020; 18: 19952002.

15. Chen YT, Shao SC, Hsu CK, Wu IW, Hung MJ, Chen YC. Incidence of acute kidney injury in COVID-19 infection: a systematic review and meta-analysis. Crit Care 2020; 24: 346.
16. Rodriguez-Morales AJ, Cardona-Ospina JA, Gutierrez-Ocampo E, et al.; Latin American Network of Coronavirus Disease 2019-COVID-19 Research (LANCOVID-19). Clinical, laboratory and imaging features of COVID-19: a systematic review and meta-analysis. Travel Med Infect Dis 2020; 34: 101623.

17. Riphagen S, Gomez X, Gonzalez-Martinez C, Wilkinson N, Theocharis P. Hyperinflammatory shock in children during COVID-19 pandemic. Lancet 2020; 395: 1607-8.

18. Godfred-Cato S, Bryant B, Leung J, et al. COVID-19-associated multisystem inflammatory syndrome in children - United States, March-July 2020. MMWR Morb Mortal Wkly Rep 2020; 69: 1074.

19. Radia T, Williams N, Agrawal P, et al. Multi-system inflammatory syndrome in children and adolescents (MIS-C): a systematic review of clinical features and presentation. Pediatr Respir Rev 2020; doi: 10.1016/j. prrv.2020.08.001. 